\title{
ANALISIS WAKTU PEMESINAN PADA UJI KOMPETENSI PRAKTIK KEJURUAN TEKNIK PEMESINAN DI SMK
}

\author{
Ade Karyadi ${ }^{1}$, Wardaya ${ }^{2}$, Purnawan ${ }^{3}$ \\ Departemen Pendidikan Teknik Mesin \\ Universitas Pendidikan Indonesia \\ J1. Dr. setiabudhi No. 207 Bandung 40154 \\ dekryadi@yahoo.com
}

\begin{abstract}
ABSTRAK
Tujuan penelitian ini adalah, untuk mengetahui gambaran waktu pemesinan dan menghasilkan format penilaian indikator waktu yang sesuai pada pelaksanaan uji kompetensi praktik kejuruan bidang pemesinan di SMK Negeri 6 Bandung tahun pelajaran 2013/2014. Metode yang digunakan adalah metode deskriftif. Data dijaring melalui studi observasi secara langsung pada pelaksanaan uji kompetensi praktik kejuruan teknik pemesinan untuk pekerjaan membubut. Jenis proses terdiri atas: membubut diameter, membubut panjang, mengebor diameter, mengebor kedalaman, membubut alur, membubut ulir dan membubut tirus. Waktu pemesinan diukur mulai dari siswa berdiri di depan mesin sampai benda kerja selesai dan diserahkan kepada assesor. Subjek penelitian sebanyak 30 siswa. Rata-rata waktu pemesinan penyelesaian produk dalam proses pembubutan adalah 213 menit. Waktu pemesinan pada pekerjaan membubut dikelompokkan kedalam empat kategori penilaian dengan standar acuan nilai dengan hasil persentase 13\%, 27\%, 53\% dan $7 \%$ masing-masing untuk kategori A, $\mathrm{B}, \mathrm{C}$ dan $\mathrm{E}$.
\end{abstract}

Kata kunci: kejuruan, pemesinan, bubut, kompetensi.

\section{PENDAHULUAN}

Berdasarkan data Badan Pusat Statistik (BPS) mengenai angka pengangguran di Indonesia pada tahun 2013, ternyata jumlah lulusan Sekolah Menengah Kejuruan (SMK) yang menganggur sebanyak $11,81 \%$ atau 847.052 orang dari total 7.170.523 orang penganggur. Angka ini menunjukkan bahwa masih belum tercapainya tujuan SMK dalam mempersiapkan peserta didik untuk mengisi lowongan pekerjaan yang ada di dunia usaha dan dunia Industri sebagai tenaga kerja tingkat menengah, sesuai dengan kompetensi dalam program keahlian pilihannya. Berdasarkan hasil observasi melalui studi dokumentasi yang dilakukan di SMK Negeri 6 Bandung mengenai data lulusan yang bekerja di industri dihitung dari tahun 2010 sampai tahun 2013. Data tersebut apabila dirata-ratakan, maka lulusan SMK Negeri 6 Bandung yang terserap di industri sebanyak $57.34 \%$ dan sisanya $43.15 \%$ tidak bekerja di industri, melanjutkan sekolah dan berwirausaha. Hal ini memunculkan pertanyaan, apakah lulusan dari sekolah tersebut kurang kompeten untuk bekerja di industri atau ada faktor lain yang menyebabkan tidak semua lulusan terserap di industri. Sedangkan kita tahu

\footnotetext{
${ }^{1}$ Mahasiswa Departemen Pendidikan Teknik Mesin FPTK UPI

2 Dosen Departemen Pendidikan Teknik Mesin FPTK UPI

${ }^{3}$ Dosen Departemen Pendidikan Teknik Mesin FPTK UPI
} 
bahwa SMK Negeri 6 Bandung merupakan salah satu SMK terbaik se Indonesia, yang senantiasa menjadi SMK percontohan bagi SMK lainnya. Sekolah ini juga telah melaksanakan uji kompetensi semenjak aturan uji kompetensi diberlakukan untuk SMK. Siswa yang dinyatakan lulus dari SMK ini telah melaksanakan proses uji kompetensi baik secara teori juga praktik.

Pelaksanaan uji kompetensi merupakan salah satu standar kelulusan siswa di SMK. Tujuan dari penilaian kompetensi adalah untuk menetapkan keberhasilan peserta didik dalam menguasai satu unit kompetensi dengan mengacu kepada standar kompetensi nasional. Standar Kompetensi adalah kemampuan yang secara umum harus dimiliki oleh peseta didik (lulusan). Kompetensi adalah pernyataan yang menggambarkan penampilan suatu kemampuan tertentu secara bulat yang merupakan perpaduan antara pengetahuan dan kemampuan yang dapat diamati dan diukur (Rusman, 2010).

Standar penilaian pelaksanaan uji kompetensi telah ditentukan oleh Badan Standar Nasional Pendidikan. Kriteria yang dinilai pada pelaksanaan uji kompetensi praktik kejuruan meliputi aspek persiapan kerja, proses (sistematika dan cara kerja), hasil kerja, sikap kerja dan waktu (BSNP, 2013). Kelima aspek tersebut menjadi standar acuan penilaian pada proses ujian kompetensi praktik kejuruan. Berdasarkan aspek penilaian tersebut yang menarik perhatian penulis adalah mengenai standar waktu pelaksanaan ujian kompetensi kejuruan, dalam lembar penilaian tersebut indikator waktu yang ditetapkan kurang spesifik.

Letak permasalahannya yaitu kurang spesifiknya standar waktu kerja yang dibutuhkan oleh siswa selama proses pengerjaan uji kompetensi tersebut. Permasalahan ini akan menyulitkan assesor dalam menentukan kriteria penilaian pada aspek waktu pengerjaan pelaksanaan uji kompetensi praktik kejuruan. Assesor tidak mampu membedakan nilai antara siswa yang selesai cepat dengan siswa yang lambat. Selain itu permasalahan ini akan berakibat pada siswa itu sendiri, siswa tidak mengetahui standar waktu penyelesaian produk yang dia kerjakan, akibatnya siswa kurang merespon pekerjaan yang dikerjakan.

Penilaian aspek waktu ini mempunyai bobot 3 dari jumlah bobot komponen penilaian adalah 25, atau sekitar 12,5\% dari total penilaian uji kompetensi praktik kejuruan ini. Meskipun hanya $12,5 \%$, tetapi pada kenyataannya di dunia industri aspek waktu merupakan aspek yang dominan dan sangat diperhatikan. Tentunya ini harus jadi perhatian bagi BSNP dan pihak sekolah untuk terus meningkatkan kompetensi siswa dalam waktu penyelesaian produk secara tepat. Apabila kriteria penilaian waktu pemesinan tidak diperhatikan, bisa berakibat pada tingkat relevansi dari kompetensi indikator waktu 
pemesinan siswa dengan kompetensi indikator waktu pemesinan yang diharapkan oleh industri (Rochim, 1993). Sejauh ini masih banyak lulusan SMK yang menganggur, fenomena ini memunculkan pertanyaan, apakah kompetensi waktu pemesinan lulusan SMK belum sesuai dengan kompetensi waktu pemesinan yang diharapkan oleh industri.

Aspek penilaian indikator waktu pada pelaksanaan uji kompetensi praktik kejuruan ini mengacu pada rasio distribusi waktu yang dilakukan operator di industri (Mardapi, 2003). Mengapa demikian, karena tujuan dari penyelenggaran pendidikan teknik kejuruan pemesinan adalah untuk menciptakan tenaga kerja di industri. Tujuan penelitian ini, yaitu untuk mengetahui gambaran waktu pemesinan pada pelaksanaan uji kompetensi praktik kejuruan teknik pemesinan. Manfaat dari penelitian ini mampu menghasilkan format penilaian indikator waktu yang sesuai, untuk digunakan pada pelaksanaan dan evaluasi uji kompetensi praktik kejuruan teknik pemesinan bubut.

\section{METODE PENELITIAN}

Metode yang digunakan dalam penelitian ini, adalah metode desktriptif. Pada penelitian ini pengumpulan data dilakukan dengan cara menghitung waktu kerja secara langsung di lapangan menggunakan stopwatch untuk memperoleh data waktu yang akurat. Waktu pemesinan dihitung ketika siswa berdiri didepan mesin sampai benda kerja selesai dan diserahkan kepada assesor untuk dinilai pada pelaksanan uji kompetensi praktik kejuruan tingkat XII di SMKN 6 Bandung Tahun Pelajaran 2013/2014.

Populasi yang diteliti merupakan siswa tingkat XII tahun 2013/2014 sebanyak 120 siswa yang terdiri dari 4 rombongan belajar. Pengambilan sampel dengan teknik sampling insidental yaitu teknik penentuan sampel berdasarkan kebetulan. Teknik sampling ini dipilih karena waktu pelaksanaan ujian kompetensi praktek kejuruan disekolah yang bersangkutan sudah hampir selesai dan hanya tersisa satu kelas, jadi penulis mengambil data hanya pada satu kelas saja.

\section{HASIL PENELITIAN}

Hasil pengamatan yang telah dilakukan dengan mengukur waktu pemesinan pada uji kompetensi pekerjaan membubut diperoleh sebagai berikut: waktu maksimum 390 menit, waktu minimum 85 menit, waktu rata-rata 213 menit, standar deviasi 58 menit. Penelitian dilakukan pada 30 responden. 
Standar deviasi yang didapat dari data diatas adalah 58 menit, ini akan menjadi patokan dalam penetuan kriteria penilaian pada setiap siswa. Apabila dimasukan pada rentang penilian yang dibagi ke dalam empat kategori. Nilai A adalah lebih kecil sama dengan waktu rata-rata dikurangi 1 standar deviasi. Nilai B lebih besar dari waktu rata-rata dikurangi 1 standar deviasi dan lebih kecil sama dengan waktu rata-rata. Kategori C ditentukan dengan kriteria lebih besar dari waktu rata-rata dan lebih kecil sama dengan waktu rata-rata ditambah 1 standar deviasi. Apabila waktu penyelesaian lebih besar dari waktu rata-rata ditambah 1 standar deviasi, maka siswa tersebut termasuk kategori E. Adapun untuk melihat gambaran distribusi kategori waktu pemesinan pekerjaan membubut pada pelaksanaan uji kompetensi praktik kejuruan bidang pemesinan. Sesuai dengan kriteria format penilaian waktu yang dibuat, diperoleh hasil pegelompokkan hasil penilaian (Tabel 1).

Tabel 1. Kategori Kompetensi Waktu Membubut

\begin{tabular}{cccccc}
\hline No & Kategori & Kriteria & Rentang & Frekuensi & $\%$ \\
\hline 1 & $\mathrm{~A}$ & $\mathrm{~A} \leq \overline{\mathrm{X}}-S$ & $\mathrm{~A} \leq 155$ & 4 & 13 \\
2 & $\mathrm{~B}$ & $\overline{\mathrm{X}}-S<B \leq \overline{\mathrm{X}}$ & $155<\mathrm{B} \leq 213$ & 8 & 27 \\
3 & $\mathrm{C}$ & $\overline{\mathrm{X}}<C \leq \overline{\mathrm{X}}+\mathrm{S}$ & $213<\mathrm{C} \leq 271$ & 16 & 53 \\
4 & $\mathrm{E}$ & $E>\overline{\mathrm{X}}+\mathrm{S}$ & $\mathrm{E}>271$ & 2 & 7 \\
\hline \multicolumn{7}{c}{ Jumlah } & & 30 & 100 \\
\hline
\end{tabular}

Sebaran data membentuk kurva miring negatif. Hasil ini menunjukkan bahwa kriteria pencapaian kompetensi siswa belum tercapai dengan baik. Gambaran pelaksanaan waktu kerja pada uji kompetensi praktik kejuruan di SMK Negeri 6 Bandung ini menjadi representasi dari hasil pembelajaran praktik pemesinan itu sendiri. Menurut pengamatan data statistik, apabila diagram membentuk kurva miring negatif. Hasil ini menggambarkan bawa terdapat gejala yang dipengaruhi selama proses pembelajaran berlangsung yang mempengaruhi hasil penilaian waktu pemesinan pekerjaan membubut pada pelaksanaan uji kompetensi praktik kejuruan itu sendiri.

Hasil penilaian yang dilakukan oleh assesor untuk aspek waktu ini, hasil yang didapatkan tidak sesuai dengan hasil yang dikemukakan oleh penulis. Hasil penilaian aspek waktu siswa pada pelaksanaan uji kompetensi praktik kejuruan di SMKN 6 Bandung tahun ini, semua siswa mendapat nilai A atau 4 poin . Berdasarkan hasil penilaian assesor, jika ditinjau dari aspek nilai, maka ini dapat dikatakan berhasil. Tetapi jika kita tinjau dari segi evaluasi yang merupakan tolak ukur kemampuan siswa, maka ini jelas tidak berhasil. Mengapa dikatakan demikian, gambaran ini bisa diakibatkan karena soal ujian yang termasuk 
kategori soal yang mudah, sehingga siswa dapat mengerjakan dengan cepat. Namun pada pelaksanaan yang sesungguhnya di lapangan, assesor kesulitan dalam menentukan kriteria nilai yang seharusnya, karena tidak ada acuan yang jelas dan spesifik pada standar penilaiannya. Jika kita lihat standar penilaian aspek waktu kerja yang BSNP tetapkan, tentu ini akan berbeda hasilnya dengan yang penulis lakukan. Fenomena ini terjadi karena kriteria penilaian dari BSNP tidak se-spesifik standar waktu yang penulis buat.

Sejauh ini, terkadang lulusan yang dianggap kompeten oleh pihak penyelenggara uji kompetensi praktik kejuruan, kurang relevan dan dinilai kurang kompeten oleh pihak industri. Terlihat dari indikator penilaian aspek waktu BSNP, indikator waktu yang ditetapkan kurang spesifik. Tidak ada perbedaan antara yang selesai paling cepat dengan yang lambat, selama mampu selesai dalam rentang 8-10 jam akan mendapatkan nilai A poin jika benda kerja yang dihasilkan memiliki hasil yang baik dan benar. Yang membedakan antara siswa yang mendapat nilai B hanya dibedakan oleh hasil kerjanya saja, jika masih dalam rentang waktu yang sama yakni 8-10 jam tapi hasilnya kurang baik namun benar. Bagi siswa yang tidak selesai tepat waktu namun hasilnya baik dan benar mendapat nilai C. Sedangkan untuk yang tidak tepat waktu dan hasilnya tidak benar dan salah masih mendapat nilai D.

Penilaian aspek waktu ini mempunyai bobot 3 dari jumlah bobot komponen penilaian sebesar 25, atau sekitar $12,5 \%$ dari total penilaian pada uji kompetensi praktik kejuruan. Meskipun hanya $12,5 \%$, tetapi pada kenyataannya di dunia industri aspek waktu merupakan aspek yang dominan dan sangat diperhatikan. Tentunya ini harus jadi perhatian bagi BSNP dan pihak sekolah untuk terus meningkatkan kemampuan siswa dalam waktu penyelesaian produk secara tepat.

Tabel 2. Tabel Kriteria Penilaian Waktu Pekerjaan Membubut

\begin{tabular}{ccccc}
\hline No & Komponen & \multicolumn{1}{c}{ Kriteria } & Kategori & Skor \\
\hline \multirow{2}{*}{$1 \quad$ Waktu Penyelesaian } & $\begin{array}{l}\text { Siswa Mampu Menyelesaikan } \\
\text { Pekerjaan Lebih Cepat dari 154 menit } \\
\text { Siswa Mampu Menyelesaikan } \\
\text { Pekerjaan 154 Menit sampai 213 } \\
\text { menit }\end{array}$ & B & 4 \\
& $\begin{array}{l}\text { Siswa Mampu Menyelesaikan } \\
\text { Pekerjaan 212 Menit sampai 271 } \\
\text { menit } \\
\text { Pekerjaan Diselesaikan Melebihi 217 } \\
\text { menit }\end{array}$ & C & \\
& E & & \\
& & & \\
\hline
\end{tabular}


Kriteria yang dibuat berupa patokan waktu pekerjaan dalam satuan menit, sehingga assesor tidak akan kesulitan dalam menentukan kategori nilai pada siswa. Instrumen ini menunjukkan penghargaan bagi siswa yang mampu menyelesaikan pekerjaannya secara cepat, tentu akan mendapat kategori lebih baik dari yang lambat. Format seperti inilah yang seharusnya dikembangkan oleh BSNP dalam melaksanakan uji kompetensi praktik kejuruan. Sehingga kriteria penilaian itu tidak rancu dan akan lebih tepat sasaran.

Hasil penilaian asesor pada indikator waktu ini menunjukkan bahwa, asesor tidak mampu memberikan nilai yang sesuai antara siswa yang menyelesaiakn pekerjaannya selama 85 menit dengan siswa yang selesai 390 menit. Dapat diartikan bahwa penilaian aspek ini tidak objektif, karena tidak sesuai dengan penilaian yang seharusnya, hal seperti inilah yang dikhawatirkan akan menjadi indikator tidak relevannya kompetensi lulusan SMK dengan kompetensi yang diharapkan oleh industri (Sudjana, 2005). Permasalahan ini jelas akan berakibat pada keberhasilan siswa dalam bekerja di industri. Permasalah ini dapat menjadi salah satu penyebab makin bertambahnya pengangguran yang dihasilkan dari lulusan SMK setiap tahunnya.

\section{KESIMPULAN}

Waktu pemesinan pada pelaksanaan uji kompetensi praktik kejuruan bidang pemesinan bubut, dengan rata-rata yaitu 213 menit, waktu tercepat 85 menit dan waktu maksimal yaitu 390 menit. Waktu membubut pemesinan 40\% siswa menyelesaikan dengan baik, 50\% menyelesaikan cukup baik dan sisanya melebihi waktu yang telah ditetapkan. Hasil pengujian dilakukan sesuai dengan standar penilian yang telah ditetapkan.

\section{DAFTAR PUSTAKA}

Badan Standar Nasional Pendidikan. (2013). Peraturan Badan Standar Nasional Pendidikan Nomor 0020/P/BSNP/I/2013 tentang Prosedur Operasi Standar Penyelenggaraan Ujian Nasional. Jakarta: BSNP.

Mardapi, Djemari. (2003). Pola Induk Sistem Pengujian Hasil KBM Berbasis Kemampuan Dasar, Jakarta: Rineka Cipta.

Rochim, T. (1993). Teori dan Teknologi Proses Pemesinan. Bandung: Lab. Teknik Produksi Departemen Teknik Mesin FTI - ITB.

Rusman. (2010). Model-model Pembelajaran. Bandung: Mulia Mandiri Pers.

Sudjana, N. (2005). Penilaian Hasil Proses Belajar Mengajar. Bandung: PT Remaja Rosda Karya. 